\title{
Account of The Algerian Urban Guerrilla Network and Its Role in The FLN's Campaign during The Battle of Algiers (1956-1958)
}

\section{Abder-Rahmane Derradji*}

\begin{abstract}
Algerian guerrilla network has been studied from different angles and perspectives within the framework of either Algerian history, or FLN nationalism. This paper is an attempt to highlight the birth, growth and demise of the Algiers Autonomous Zone, (ZAA) as was launched by the FLN in mid 1956 in Algiers. Its aim is also to investigate the FLN urban guerrilla and terror network in general, and see its impact on the Algerian rural campaign, including strategy and tactics. Accordingly, it will also search French counterinsurgency response using French paratroopers and institutionalisation of extensive torture as well as, interrogation to extract information from FLN captured guerrillas.
\end{abstract}

Key Words: Guerrilla \& urban guerrillas, terrorism, nationalism, Jihad, Counter-terrorism,

*Assoc. Prof Dr, Remote political Analyst IHS London \& Former Lecturer, aibi17@yahoo.co.uk 


\section{Introduction}

The division between rural and urban guerrilla in Algeria is important for two reasons: First, for the adopted general campaign strategy by the FLN (in 1956) and second, for the sake of exploring FLN military tactics and their effects on the overall war. It is also worth, knowing for instance, to what degree did the rural converge, or diverge with the urban? And what did the urban network bring to the rural countryside and campaign and at what cost? By answering these questions, one will undoubtedly, be able to identify the points of strength and of weakness in both strategy and tactics and therefore, draw a picture of the whole FLN campaign.

The selection of this example (urban network) is due to a number of objective reasons: first it was due to high urbanisation and being the Capital where concentration and centralisation of government colonial institutions are placed, to the FLN changing patterns in styles of fighting to the development of the FLN organisation structure itself and its effectiveness in Algiers than any other urban cities, like Bone (Annaba), Constantine or Oran to the west. But the most important reason for selection was however, mainly due to its strategic importance and meaning. It is worth remembering that Algiers ${ }^{1}$ was as mentioned the colonial capital of "French Algeria" where most businesses were found and this from a military point of view was seen as a suitable target and meaningful to the FLN. In order to know its impact on the overall strategy and tactics of the FLN, it is undoubtedly crucial to diagnose the organisation (ZAA) itself and search the causes of its strength and weakness. As cited earlier, that the decision to launch an urban guerrilla and terror network in the city, notably, in Algiers, was not a very easy task. The FLN leaders debated the issue for days before approving the decision. Hot discussion and controversies of what might result and impact upon the outcomes of launching a terror campaign on the overall FLN revolution and its people were very preoccupying issues. In the end the FLN found itself divided between supporters of the idea and those who promptly rejected it on the ground that it might harm the revolution and lead to a total collapse. In the end, it was the supporters, like Abbane Ramdane, Youcef Benkhedda who endorsed it and approved it. Further it is important to add that those who supported it and came as one of the key Summam resolutions has been solely decided without the consent of the FLN external delegation. This as the war developed, and beyond would mark a crack within the Algerian nationalist body forever.

\section{Diagnosis of Algiers Autonomous Zone (ZAA)}

When the insurrection of November 1st 1954 broke out, the French Europeans 'Pieds-Noirs' of Algeria and the French authorities received the first FLN attacks with great panic, but not seriously, especially at the beginning thinking of it as a simple common, ordinary crime, or rather residual terrorism. And soon, newspaper' headlines started reading these facts as simple terrorism, then the media further ideologised it by informing of a communist conspiracy and an internal plot by Soviets' lackeys. But once the FLN challenged with circulation of pamphlets and endorsed it with bullets, worries began to mount and France, including French official media began to broadcast and inform of 'Hors La Loi' outlaws, bandits, rebels and terrorists. The Algiers urban guerrilla movement and its terror network was therefore, part of this overall revolutionary unrest, which should be considered as a distinctive and different form. This came with its different nature, pattern and origin far from any other nationalist communist insurgency. It combined a number of factors like secular nationalism, populism, Islamic Jihad as well as, Algerian ethnic identity.

The initiation of urban network started first of all, with high secrecy, organisation and control over the whole Muslim civilian population learning from the old secret organisation, or "Organisation Secrète" of 1948 expertise and mistakes as well as, from old Emir's era (1834-38). With the emergence of new FLN objectives, and as the rural guerrilla campaign developed, the urban underground created a new organisation, with new tactical methods. Since the first November appeal of 1954, Algiers and its city-dwellers were in fact, relatively ready for action and only, waiting for the 
"Green light" from the FLN movement directives to strike at French targets, including 'civilians' of European origins. Assassinations and attacks on revenge and passionate grounds, were however of daily news in the quarters and alley-ways of the Kasbah, but those attacks were mainly done on individual basis and initiatives rather than instructed by the FLN. Revenge and retribution tend to be the symptoms of the cycle of violence prior to the Battle of Algiers, especially in sub-urban quarters where working class commute.

As cite earlier the emergence of key figures, like "Abbane Ramdane as a generator of the idea of "urban terror" (A complementary tool to the rural guerrilla], and with the assistance of other FLN militants, viz: Youcef Ben Khedda, instructions were given to the Kasbah inhabitant leader, Yacef Saadi, to fasten the organisation process and give birth to the first urban network. So the Algiers Autonomous Zone known or the ZAA was finally set up". Of its 700,000 inhabitants, 400,000 of them were Muslims providing the FLN with both support and intelligence; and made it very easy for the first clandestine underground to get quickly established. The setting of the organisation had a very complex structure, and remained, for months a real enigma to the French police, army and intelligence services. Organisationally, at the summit, was the Zones' Council or "Conseil de Zone' consisting of four men, the politico-military chief and his three leader assistants who were respectively involved in three main branches: Military, politico-financial and intelligence." 2 The military branch was presented in every single region and was essentially, formed of three armed operative groups. Each one contained three guerrilla cells of three armed men, including chiefs and their assistants. The number of active militants was around thirty five men per region. Their role was, however, assigned to armed attacks, executing FLN instructions, as well as punishing disobedient and traitor informers. As for the politico-financial branch, its duty was in controlling the structure and watching over the behaviour of the entire population through what was termed as cleaning up operations within the city, and in also raising funds for the organisation. ${ }^{3}$ In practice, however, this set up appeared as a multi-function body dealing with a number of duties. For example, on intelligence matters, the network instructed the sub-division of duties into sectors and cells, as well as in forming various teams with different missions: One, was for instance in charge of producing tracts and propaganda means, another group (formed of 50 to 70 armed militants, and divided into sectors) responsible for armed actions and was also, organised into groups of choc, and another one purely assigned to the security of transport means and logistics for the guerrillas and other supplies. In addition, there was also, another special, extra group of militants operatives purely specialised in indoctrination through a dual hierarchical system. One was directed at individuals, whereas the other, was targeting industrial enterprises and corporate administrations. Beside the armed missions, which the urban guerrilla volunteer Fidayeen ${ }^{4}$ had to fulfil, their duty was also to provide shelters and secure hidden places for their leaders, as well as letter boxes to their agents of liaisons for messages' exchange..

\section{Underground \& Secrecy}

Clandestineity as a vital guerrilla means for survival was from the FLN's point of view, necessity and a condition for the Autonomous Zone's strength. At the operational level, for example, the network was given an important priority and was taught to the urban guerrillas individually, especially on how to behave in case the network loosens or been discovered by the French police. ${ }^{5}$ This chain was secured by a significant control and specialism where every single militant had to operate within his or her own field and zone and according to his or her structural echelon and instructions. At the base, the militant knew, for example, only the Chief of his or her cell. Practically, the liaison of command was not secured by personal contact, but through letter-boxes and other clandestine networks called "Réseaux". These were however, exploited by an agent of liaison who was himself attached to a chief, the only one entitled to know his or her shelter. Yacef, Saadi, the head of the Autonomous Zone, noted in this respect that "Within the same month of February, I have changed my refuge seventeen 
times". ${ }^{6}$ The idea behind changing places, passwords and pseudo-names (which were frequently changing according to circumstances and nature of missions), was twofold: first, to deepen the French confusion and second, to preserve the safety of the organisation and its members. The complementary work of the above cited branches, which frequently appeared inter-changeable in duties, made it difficult, especially at the beginning, for the French authorities in occupied Algeria to spot or detect it. To set up a counter-strategy with the view to find it and destroy the whole network was the main French policy of the time. The FLN in contrast, multiplied its actions and diversified its terror operations by keeping divided specialised urban guerrilla work within its sub-urban cells. This secured their cohesion and secrecy maintenance at least for a while. ${ }^{7}$

At the military level for instance, there was also another group formed of "Networks in Sleep", or "Réseaux en Sommeil" ready to replace any structures or groups already destroyed or dismantled by the French intelligence or forces. This was, in fact, almost similar in action to the Réseaux de reserve" (Reserve-Networks) that were formed during the first depression of the organisation. ${ }^{8}$

High secrecy, on the other hand, also, remained in what the FLN urban fighters considered as a "top secret". This was, however, allocated to the (bomb-network) which gave the campaign an important meaning and strength in propaganda as well as publicity. Phillipe Tripier noted that "It represents (the Réseaux of bombs) the most privileged instrument of action of the zone and which was directly, subjected to the ZAA's chiefs and orders. It consisted of four branches: The base (carsasserie), the explosive fabrication device and adjustments, the timing and electrical detonators, and the transportation"..

In order to make control successful and strengthen the organisation, Yacef Saadi started the recruitment process (from the base) i.e. the inhabitants of the Casbah and began from the lowest social strata of the Algerian Muslim society. He began his duty within the Arab quarters, or what he himself called "Le milieu or the pimp's circles" (outlaws, convicts, victims of French colonialism). In his book "La Bataille d'Alger" he assumed that his preference went, first of all, towards the most segregated, oppressed and hated outlaws, "La Pêgre". ${ }^{10}$ He saw that these Marginal individuals were in fact alienated by colonialism; they were partisans of action, ready to face the enemy at any price or risk. Their integration (if succeeded) within the FLN's ZAA of the urban city would be of a great value and beneficial to the Algerian revolution. Saadi, who was himself originally, from the Casbah, knew his region better than anyone else within the ALN men. He knew its twisty enigmatic alley ways as well as, its secured and dangerous hideouts. His selection of the people of the "milieu" to form his first nucleus of the urban guerrilla was therefore, very strategic to the organisation. He knew that people of such circles, who were front line fighters, would be less inclined to draw back in front of the colonial enemy, because of their unlimited courage and black records. ${ }^{11}$ Further, the ' $\mathrm{La}$ Pêgre' ${ }^{12}$ which emerged, due to social and economic problems in Algiers (as a result of French colonialism), was at its peak, and if not exploited by the FLN to gain control over it, it would threaten the entire network. The most worrying factor, furthermore, was that an important part of it was already operating under French secret police control and working for them as informers. So, in order to break this barrier and convert those to the movement and the Algerian FLN's case decided to dominate the city by waging a war of nerves and intimation. With the help of Ali La Pointe, ${ }^{13}$ (an expimp, gangster and a boxer) Yacef Saadi managed to make the first contact with the most notorious pimp-underground. Men like Mustapha Bag, Akhoul, Mustapha aka "DJITA" and Gasseb Rabah aka le Chlore and Mohamed Seghir or Little Moh with his entire group, were amongst the first converts to the FLN cause. Those who, however, refused to co-operate with the FLN or claimed neutrality, became soon the first FLN targets. The procedure of terror and execution were left as the last resort to use in order to bring allegiance and obedience to the ZAA in the city of Algiers and its suburbs. Behind the cleaning-up operations, the FLN in general and the ZAA in particular were aiming at the 
purification and cleansing the city of Algiers, notably the Kasbah, from all forms of social and political parasites and at also, suppressing any other competing force than the FLN in general.

Yacef noted that "To transform the Kasbah into a liberated territory was our hope... our first initiative consisted of launching an operation of intimidation against the milieu." 14

It is important to add however, that Algiers city was almost all under the control of the "Pimp-criminals". For example, the Kasbah was divided into "higher" and lower parts, totally under the control of an outlaw called Abdelkader Rafai aka "Bud-Abbot", the quarters of "De La Marine" and part of Bab el Oued regions were allocated to Hocine Bourachi aka Hacène Le Bonois. As regarded the lower Kasbah, it consisted of La Rue Barberouse, Katarogy and Bologhine, and was given to Abdelkader Houya, leaving the rest of the old town shared between the so-called "independents" viz.: Mostapha Mey, Babouche, Boualem Buvetta and others.

Most of those were in fact, given "carte blanche" to carry on their Pimp-jobs provided that they would feed the French police with useful information on FLN's men and spy on their supporters. But despite their protected actions, the FLN far succeeded as it went along by executing most of them and winning the campaign through persuasion and coercion. ${ }^{15}$ But despite the successful suppression of the underworld brigandage including the lower Kasbah pimps, the ZAA urban guerrillas had still to face other political competitors, notably the Messalists or the MNA groups that were well equipped militarily, organised and counted into thousands. ${ }^{16}$ Yacef noted that "The list of our killed partisans was growing. Amongst them were Abdelkader alias "petit Negro" who was assassinated at La Rue bleu near cinema Nedjma and Ahcène Laskri, the political leader of Algiers sector, without counting the attacks of armed groups firing at cafés and merchants who were judged as Pro FLN". ${ }^{17}$ In order to confirm its mastery and control over the city, the FLN had to draw a four-objective programme: First, to detect the Messalists with the aim of liquidating them;, second, to develop a counter-propaganda network by informing the Muslim population and denouncing the real face of the MNA vis-à-vis the French administration; third, to attempt winning the hearts of their rivals by converting them into their ranks, and finally fourth, to infiltrate the MNA organisation and proceed with its destruction from within.

\section{Popular Support, Mobilisation and Propaganda}

After the achievement of the war on the milieu, the Algerian urban fighters were confronted by further enemies, the MNA group. On the one hand, they were fighting MNA groups on ideological grounds, and the French colonial administration, and on the other, competing with the MNA Messalits who would win hearts and souls of the Muslim population. So, in order to find key issues to bring about popular support to the cause, both movements resorted to different methods (conviction and coercion).

The other challenge was coming from the French Pieds-Noirs Europeans. For this, the FLN was more relaxed due to the nature and behaviour of this latter. It is important to add that the racial and cultural divides between the two communities (French pieds-noirs and Algerian Muslims) was helpful for the FLN that was well controlled in transmitting the idea of the armed struggle against French settlers and the colonial administration as well as their lackeys. The Fidayeen and Fidayait (volunteer fighters ready to die at any time or place) personally interviewed had revealed that there were two distinctive communities in contrast to what had been claimed and argued by some historians. ${ }^{18}$ These were located in very segregated quarters, and estates almost similar to the South African model of apartheid. For example, the best areas of la Grande poste, Boulevard Victor-Hugo, the rue Michelet with its luxurious shops, cafés, cinemas, the higher areas of La place du gouvernement, Square Bresson-Port Said, Rue Baba Azoun, les Rampes Rovigo et Vallée were entirely the monopoly of the French pieds-noirs of European origins. ${ }^{19}$ While, for example, part of 
Belcourt and $\mathrm{Bab}$ El Oued were inhabited by the European working class, the poor quarters of Belcourt and the slums of its suburbs, as well as the over-populated Casbah, were entirely occupied by the Algerian civilian Muslims. ${ }^{20}$ Furthermore, racism and prejudice were so intense to the degree of rarely finding a Casbah inhabitant at a French table eating, or drinking. And accepted as housemaids were, generally treated as second-class citizens, if not as second class humans with a low degree of intelligence, as the French believed. Pierre Chaulet noted that "The quasi totality of the young Europeans ignore the Casbah and do not see the shanty towns. The Algerian women who go to the European quarters do so, only by necessity and veiled". ${ }^{21}$ Tactically, it is worth noting that there were two, important but provocative incidents, which the FLN had cleverly exploited and used in order to bring further popular support to the FLN cause in Algiers. First, the bombing of La rue des Thébes; (organised by the Pieds Noirs against Muslims), and second, in the Kasbah itself, the French execution of two FLN men, Zabana and Ferradj. As a result of these two key incidents, the FLN far succeeded in rallying not only the local population, but in also, strengthening its recruits found amongst the angry men and women ready for arms.

The idea behind this tactic was first of all, to also, intimidate the French Europeans who would automatically retaliate in retribution against the Muslim civilians, and as a result, the situation would automatically, lead to an inter-community fighting. Through this state of disorder, which in fact, occurred, the FLN emerged with great skills, successful in exploiting the environment and propagate the idea of nationalism and campaign whilst guiding the Algerian Muslims, who were psychologically, and physically, ready for a revenge war against the Pieds-Noirs, especially the youth. Soon the Kasbah became a real guerrilla fortress, threatening not only the French authorities, but also the settler Pieds-Noirs. These were in fact, some of the first seeds of what became termed as the Battle of Algiers.

Edward Behr noted that "The Algiers Kasbah was a superb natural hiding place; despite French claims that at no time were more than 4,500 Algerians directly concerned with terrorism out of a total Muslim 450,000, it seems certain that the "terrorists" benefited from the complexity of a huge majority of the Muslim population as well as from the aid of a small number of Europeans. Among those arrested and convicted for having taken a major part in "terrorist" activity during this period, were employees of the Algiers gas and electricity services, postmen and post office clerks, students, doctors, tradesmen, custom officials, even Muslim police officers and a prominent Bachagha, the "Bachagha" Boutaleb, whose nationalist sympathies overcame his basically pro-French sentiments".22

Through the formulae of persuasion (that was the most factual element), indoctrination and coercion, popular support was finally accomplished and control was therefore, achieved. The ZAA FLN, still operating in secrecy, began soon to act as a "dwarf state" and exactly copying the rural guerrilla that was already based at the East and West borders, and dealing with all welfare and warfare matters like, Justice, finance, politics, military as well as medical health care. ${ }^{23}$

As has been stated earlier, the success and achievement of popular support was mainly, due to the readiness of the Muslim population that was already oppressed and segregated by the French colonial administration. And under those circumstances, the FLN did neither need to turn back to the colonial history and remind the civilian Muslims of their resistant ancestors, nor to remind them of the notorious Massacre of May $8^{\text {th }} 1945$ and other French atrocities. These were in fact, viewed, experienced and daily lived by the Muslims. As a result of alienation and oppression, which civilian, Muslim population experienced, this increased in them a sense of aggression and revenge to the extent that some Muslim house-maids savagely killed their personal French European employers. Real FLN popularity also, came openly and publicly, into view during the 8 days' strike ordered by the FLN to inform the United Nations about the Algerian cause and to confirm the Muslims' will to fight against French colonialism. This unexpected incident called quickly upon the French army to suppress it and to use brutal force. "By the evening of the 27th, Algiers was already a dead city, the 
next morning, Monday, the shutters of the Muslim shops remained down in their overwhelming majority; workers in the essential public services failed to turn up: school children stayed at home; army helicopters scattered leaflets over the Casbah, and jeeps with loudspeakers roamed the streets, ordering the population back to work." This campaign was also, endorsed by massive Paratroopers force where "...Massu showed his mettle, applying the full force of his division. Armoured cars arrived, attacked hawsers to the closed steel shutters of the shops, and simply dragged them off their fixings. Similar scenes took place over the rest of the country; in one centre of the Mitidja, Colonel "Antoine Argoud" went so far as to fire a tank shell at point-blank range into a shuttered shop... fleets of trucks were despatched around Algiers collecting strikers at their homes and physically hustling them off to work... on the first day of the strike the postal and telegraph service reported seventy-one per cent of its Muslim personnel absent in the Algiers area, forty-one per cent in Oran and only twenty-eight per cent in Constantine; on the railways there was an almost total walkout in Algiers, fifty per cent in Oran and twenty-five per cent in Constantine". ${ }^{24}$

Most western writers on Algeria, mainly Martha Crenshaw, Dorothy Pickeless, John Talbott, Edgar O'Ballance and, to some extent, Alistaire Horne and Edward Behr, explained FLN success, especially its popularity and allegiance, by the use of terror and coercion against the Muslim civilians, leading others to sometimes, take this fact for granted and without considering or investigating other causes. It is worth adding that other misleading fact was that the portrayal of the Algerian model as totally similar to other experiences when dealing with popular support, like in for example, divided Vietnam in Indochina or other communists in Latin America. In fact, despite similarities of national liberation movements and nationalism, the Algerian model rests rooted in its peculiarities, and characteristics. Secular nationalism was carefully matched with theological creed, which produced a highly successful hybrid concept of popular resistance using communist and non-communist tools of fighting.

There are two important factors which most of the literature has neglected and which were interchangeably used during the campaign; secular nationalism and holy jihad. The generation of these two matched concepts and the use of some Viet Minh tactics at the beginning, gave the reader on Algeria an impression that the guerrilla model was a left wing in origin and operating within its orbit. The fact was that Algerian experience as said earlier, did and does not fit this classification, because of its different nature, and Islamic traditions, including Jihad, that had shaped the entire campaign. Further, it would be an historical distortion and an academic mistake to assume on the other hand, that for instance the entire campaign (from 1954 until 1962) was exactly fought, and conformed with Islamic traditions since Prophet Mohamed (PUH), or was purely, conducted as a secular nationalist as had occurred in Europe during the French resistance. The combination of Jihad in its religious sense matched with Secular nationalism, were in reality, the mirror reflection of the FLN's first planners. It is also worth adding that the Frontists were neither politically, nor religiously homogenous. Their revolutionary commitment was one, but their political ambitions were indeed diverse and different. Confirmation of this diversity soon manifested in post-war independence when score settling began to come to the open and led to even physical liquidation.

Amongst FLN ranks one could observe that there were liberals, like Ferhat Abbas, left wing nationalists, like Boussouf [Founder of FLN security services] and L'Arbi Ben M'hidi, [Expert on guerrillas' organisation], communists who joined lately and more important, the religious followers of the Ex association of Islamic Ulama Scholars, like Commander Chaabani, (executed during the last phase of the war).

In order to understand this phenomenon, one may find it, however, useful to know what was the impact of both Islam and nationalism upon guerrillas in the city and what were their degrees in strengthening and preserving the general morale of the Muslim fighters on the battlefield. 
As broadly known, the Algerian indigenous people are Muslims, where Islam as a religion has a long tradition, and often been equated with the cultural heritage and patrimony of Algeria and Algerian personality. ${ }^{25}$ In principle, Islam as a universal faith, claims loyalty over all divine and positive religions, including Christianity, leading to the argument that all colonising Christians of French Algeria during the war were to the Algerian Muslims, invading infidels. So, striking against them was, therefore, not a simple performance of violence, but was a spiritual duty of every single man or woman capable of holding arms, because the assumption was that they were fighting for the Muslim cause against the enemies of God and motherland. Accordingly, religious and nationalist struggle as well as, responsibilities was totally shared besides FLN's Nationalism. On the other hand, secular nationalism with its 19th and 20th century extremism also increased the will and idea of the armed struggle, as well as, the desire of joining FLN ranks in the city of Algiers and in metropolitan France. ${ }^{26}$ As a result of this combination, the Algerian urban guerrilla fighters fought a national secular war using 20th century subversive means, but still keeping their Islamic sight in shape. Though Nationalism as a secular ideology and Jihad (as a theological ideal) are in essence antagonistic vis-à-vis each other (in strategy and motivation), the FLN had successfully managed, with great compromise, to merge them into one revolutionary creed. National pride and heroism to die for the national cause was seen as part of the religious faith of the Fidai as were exactly the belief in the concept of martyrdom, and life sacrifice. "The Fidai [Islamic guerrilla volunteer ready to die for the cause] was a conscious volunteer who did not need to absorb drugs in order to confront the danger. Most of the time, he went on a mission without return, to either get caught or be killed on the battlefield." ${ }^{27}$ Also, "...Frequent death and condemnations did not deter the urban fighters; or cause them to retreat, or cease their armed attacks. On the eve of June 19th 1956, for example, the number of condemnations to death in Barberousse-Prison of captured guerrillas increased to forty.". ${ }^{28}$ amongst those were "Zabana, Ferradj, who had been under sentence for many months, were guillotined in Barberrousse prison after Lacoste - under heavy pressure from pied-noir public opinion and wanting to placate it so as to push through his own intended "bill of rights", or Loi-cadre - had refused clemency. In the appallingly over-crowded prison where conditions were already atrocious "It is hell", wrote Bitat, who was already imprisoned there, "Men are beaten with iron bars, the heat is horrible and they are given salted water to drink", the immediacy of the executions - the sinister preparations, the defiant shouts of the condemned, the very audible thud of the blade provoked most violent reactions, and these were amplified outside. To the Algerian mind such judicial executions were particularly shocking... Announcing that for every guillotined member of the FLN, a hundred French would be killed indiscriminately, Ramdane Abane ordered immediate reprisals". ${ }^{29}$

\section{ZAA Military Tactics and Space}

In order to better understand the role of religion and revolutionary terror and their impact on the FLN campaign, an intensive survey was needed. Based on a random sample, we selected three months: (January, May and August for the year 1957) where the cycle of violence (whether coming from FLN-ZAA guerrillas, or the French army and the Pieds-Noirs) was at its peak. We then, collected around 951 recorded cases on different types of violence extracted from the French Newspaper "Le Monde" and the FLN's wartime Newspaper Al Moudjahid for the same year. The intention was to compare the two sources, but due to the shortage and unavailability of news reports during that same period the task was unsatisfactory. It was found out that the war-time era was very difficult to enable the FLN, for instance, to collect updated news of its dispersed war-time Wilayas and other vulnerable cities, especially when communications between those was not easy. So, instead we selected only 159 observations for the months of June and August 1957, and a few cases from January 1958. The decision was to then focus on the French source bearing in mind the fact of propaganda and psychological warfare, but without losing shape of the FLN's source too. The next step was to diagnose the collected news by describing guerrillas and counter-guerrillas' operations, tabulating 
them and storing them into different entries. For instance, noting the day of the incident, the military operation and its carrier (an FLN man, an MNA fighter, a civilian or a French Police or soldier), the place of the operation, the weapons used in order to confirm the nature of the incident as being rural or urban, and finally the objective target of the attacker. Then, we number-coded these cases using SAS programme. After a combination of various entries, we obtained different frequencies reaching controversial explanations. The results had shown, for instance, that days of religious meaning such as Fridays for Muslims, Saturdays for Jews and Sundays for Christians represented an important frequency as far as the pattern of violence was concerned. According to the FLN's source for the period of June and August 1957, and few observations from January 1958, Saturday was the most violent day in the week scoring a frequency of 39 followed by Sunday and then Friday. The explanation of this, however, is that Friday, which is an Islamic day for gathering and congregation in mosques and where Muslims discuss their daily preoccupations, tends to be in general a day of emotion, of religious enthusiasm and more important, a day of preparation for jihad, especially in war-time period. In Algeria, the mosque was besides worship, the best revolutionary school to attract volunteer Mujahideen and front line Fidayeen to die for the cause. It is not therefore, surprising to see Saturday, which is the following day, enjoying the highest score in violence (see Figure 1 for more details). On the other hand, Sunday which has generally also, a Christian meaning requires in principle a religious service and a ceremonial gathering and this from FLN guerrilla point of view, was seen as a suitable target to strike at. Yacef Saadi the head of the ZAA, was once believed to have warned the pieds-noirs, on one Sunday that they would not go to church that day while instructing his men to carry out spectacular attacks and bombing missions.

Figure 1: A detailed chart portraying guerrillas and counter-guerrillas operations per week for the period of: June, August 1957 and part of Jan 58;

\section{According to FLN Sources:}

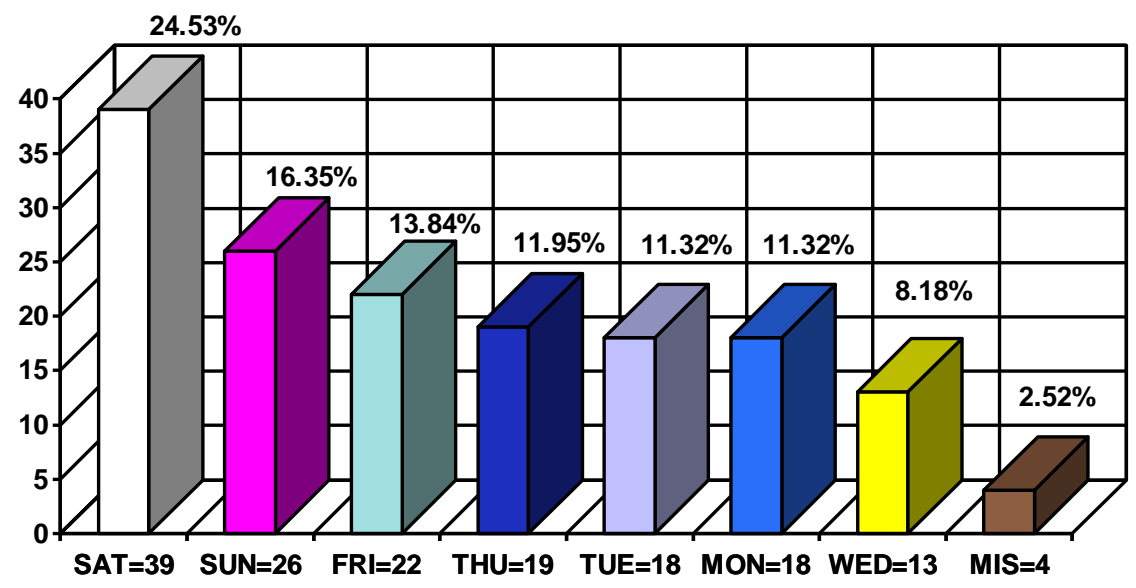

(FREQ UENCIES)

As for the French source for the period of January, May and August 1957, it was not the case. Wednesday appeared as the most violent day in the week with a frequency of 182, followed by Thursday with 135, then Tuesday with 132, whereas Sunday was the weakest of all with a score of only 25 (see Figure 2). How can we explain this enigma? Was it because of the French delay in reporting Sunday incidents or was it due to other factors? News and written media should be taken with flexibility, especially during war-time periods. Propaganda (war of nerves) and euphoria often tend to play a part in either boosting or affecting the morale of the targeted subjects; whether being the army, or civilian population. 
Figure 2: A detailed chart portraying guerrillas and counter-guerrillas' operations per week for the period of: January, May and August 1957;

According to French sources:

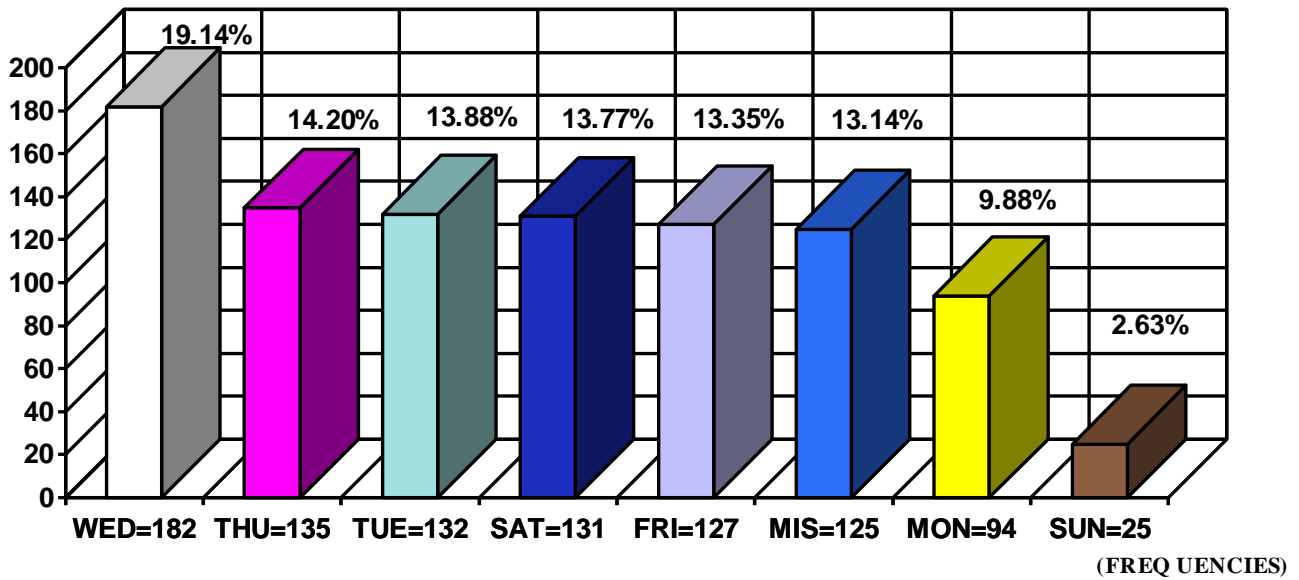

In order to overcome this ambiguity, the month of August was selected for the year 1957 for both conflicting sides to see for instance, to what extent violent days converge. As a consequence, the given results finally, portrayed and confirmed that Saturday was the most violent day of the week (see Figures 3 and 4). The religious explanation of this was that Saturday (as far as the Judaist faith ${ }^{30}$ was concerned) also symbolised synagogue-goers who were again perceived by FLN guerrillas and by some French anti -Semitic groups (confirming inter and intra communities groups) as direct targets. But, generally speaking, it can be argued that despite the fact that religious days (Fridays, Saturdays and Sundays) had played a role in promoting violence, they were seen by the two main rivals (FLN guerrillas and counter guerrillas) as days of week-ends and relaxation where cafés-maure, taverns, open markets and other public attractions were fully crowded. This, as the two rival communities' perceptions went, represented a vulnerable target.

Figure 3: A general pie chart displaying guerrillas and counter-guerrillas attacks on various targets per week; according to French sources:

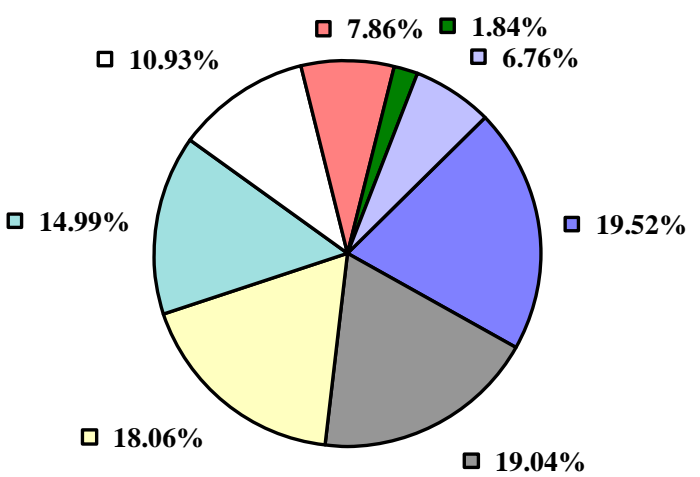

FREQUENCIES :

AUGUS T 57 


\section{Figure 4: A general pie chart displaying guerrillas and counter-guerrillas operations per} week; according to FLN sources:

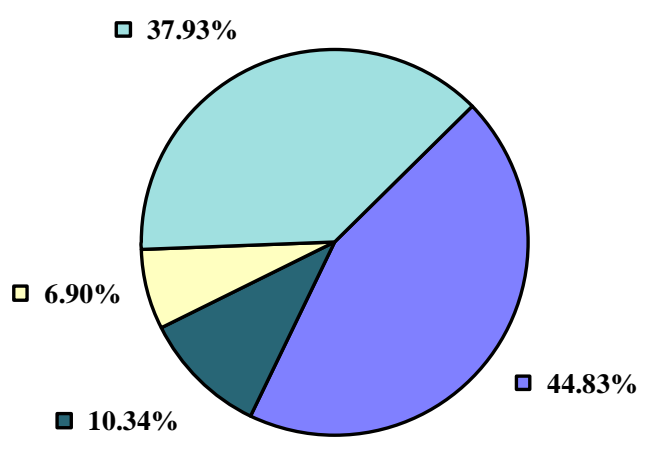

FREQUENCIES :

AUGUST 57

FLN urban, unlike rural guerrillas, relied upon Fidayeen and Fidayait without uniform. They were fighting in the city, and were prepared for delicate missions. On the battlefield mainly in urban cities, they were operating as civilians without uniform and very dedicated (as groups of choc) to amount spectacular attacks and other diverting sabotage missions. Nevertheless, this did not exclude them from also, being; furthermore, ALN Mujahedeen since the struggle was complementary to the rural countryside. They were called to die for the cause and carry out operations known in Western Lexicon as "suicide missions". Their difference from the rural partisans was in their extended duties: in the domains, terrain, striking-methods, objectives, as well as in strategic planning,

Geographically speaking, the ZAA members were bound to fight in the urban and big cities like Algiers and its suburbs, notably, in the Kasbah for the very special status that was given to the capital at the Summam Conference in 1956. Militarily, the urban city was their revolutionary nucleus for strategic and tactical purposes. Their other task was to avoid rural missions at all costs, unless they were forced and was very necessary as a last resort. The strategic position of the Kasbah and its enigmatic construction made it very easy for ZAA members to operate using hit and run tactic, especially when being chased by the French police, or paratroopers. Further, the complexity of the houses' establishment and the position of walls that went from widest to narrowest alley-ways also, assisted them in developing a skill of striking at French targets and then quickly, regaining their hideouts for refuge. The fact was that the architectural construction of the Kasbah and its position had done a great service to the FLN guerrillas in improving speed and mobility and more important, in providing - especially at the beginning - secured shelters. Arthur Campbell noted that "The Kasbah in Algiers, to many a place of mystery and romance, was no more than a festering canker attached to the heart of a civilised city. Within its walls, crowded into squalid houses, tenements, cafes... lived the majority of the city's Muslim population, 450, 000 in number. The crumbling buildings tottering over narrow, fly-locun streets and rubbish-filled yards were connected by an elaborate network of secret passages and stinking alley-ways. Inside this natural hiding place there lurked four thousand 
"terrorists", their efforts directed by Yacef Saadi and his henchman Ali Ammar, known as "Ali la Pointe." 31

But on shelters' construction and secretive hideouts Alistair Horne further remarked that "knowing every inch of the tortuous alleys of the Casbah, so narrow that one can often jump from one roof top to another, and where one square kilometre housed a teeming populace of 100,000 Muslims, he (Yacef) had persuaded Abane of the advantage of purging it of all doubtful elements and turning it into a fortress from which a campaign could be launched. With the aid of skilful masons, Yacef had created a whole series of secret passages leading from one house to another, bomb factories, caches and virtually undiscoverable hiding places concealed behind false walls". ${ }^{32}$ Strategically, the urban fighters were also, not aiming, like rural guerrillas at liberating zones, or at destroying the military machine of the enemy, since this latter's superiority was very significant and totally impossible, their objective was in contrast, how to bring the city down to its knees, to instil a state of fear and insecurity amongst the French in uniform and the European civilians and to gain more publicity, for the Algerian cause by winning headlines and this it far succeeded despite its setbacks. That the " 1956 violence had reached an unprecedented crescendo. Yacef's organisation, now effectively and deeply rooted, and with its morale boosted by France's defeat at Suez, had both Muslim and European populations of Algiers in a grip of terror. Schools had remained closed in October; Europeans took to going out the streets with automatics concealed on them, and when they saw a Muslim walking behind them on the pavement they would slow down to let him pass out of fear of an attack from behind" ${ }^{33}$ The other objective behind the "Battle of the City" however, was publicity and internationalisation of the FLN cause and this, as the conflict intensified, was carried out through massive guerrilla operations, and by publicly striking at French targets getting more positive results in Algiers than out in the countryside. Abbane Ramdane -who was behind this strategy as mentioned earlier- advised once that "Even if we take risks, our struggle must become known. We could kill hundreds of colonialist soldiers without this ever being publicly announced". ${ }^{34}$ According to him, killing publicly one in the city was more valuable - as far as publicity was concerned - than a hundred uniformed men in the countryside. So this idea was formulated and therefore, put into practice, but at a cost. The military operations in the city provided in reality, a great help for the FLN guerrilla network, because the detection of its fighters at that stage was impossible. Logistically, the network of home-made bombs and explosives became thereafter, a direct substitute for small pistols and the white arms like (knives and the like) developing a new deterrent for the network whilst strengthening FLN-ZAA position in action. ${ }^{35}$ Young women known as beach bag carriers were also recruited for such delicate missions where they played a significant role in passing these devices and in transmitting to the urban Fidayeen messages through French paratroopers' road-blocks. Yacef stressed that "We generally, used women in the social services of the zone, but Drif and Samia exceptionally preferred the action". ${ }^{36}$ The successive bomb attacks and armed raids had in response, called for French police, as well as for military forces to retaliate. Thus, under recommendations of Robert Lacoste, Paris was urgently, contacted and the decision was led to a setup of special operations called "Chasse a la Bombe". But despite French pressures and counter attacks, the FLNZAA still survived at this stage through the maintenance of mobility leaving the Casbah, and frequently, changing headquarters to other suburbs.

\section{The Communist Connection}

As had previously been seen the communists of Algeria took a neutral position vis-à-vis the first insurrection of 1954, and justified their views that time was not ready yet to launch the armed revolution. The communist view, as the FLN perceived, did not properly consider the first aggression of 1830 and its disastrous consequences on the Algerian people, and this despite their good exposure of the question of colonialism around the end of the year 1920. Accordingly, the communists, in Algeria, remained throughout the war, a source of suspicion by the FLN nationalists. ${ }^{37}$ Mohamed 
Teguia stated that "we have to observe that the UDMA, the MTLD Centralists and Ulamas were not running after the FLN to build up a contact but it was the FLN's initiative that was decided at the summit. As for the communists, it was the reverse. They (the communists) were attempting to meet the FLN men and to build these contacts for more than a year, but without success. ${ }^{38}$

As the FLN campaign developed the communists as individuals began to show sympathy and look for serious contacts, since at the beginning, it was very difficult for them to build contacts. Suspicion and mistrust remained between them, even after their formal agreement on July 1956. For instance, although an FLN guerrilla, like Bachir Chihani (Successor of Mustapha Ben Boulaid in countryside, Wilaya one) welcomed during his imprisonment, for example, Mr. Guerrouf, (a former communist who individually joined, with others the FLN ranks in wilaya one, contacts with the ALN (FLN military wing) were totally cut off after Chihani's death. In the city at the operational level, however, the network was insured by an FLN operative, named "H'didouche" whom with the help of ZAA leaders, instructed a Fidai, named "Benacer Moh Arezki" aka, Tawfik to insert the new communist comers into ZAA organisation. But officially, it was Abbane Ramdane in Algiers, assisted by Youcef Ben Khedda, who had in fact, initiated this contact and secured co-operation with the communists in a number of domains. For example, communists provided the FLN with help during time of depression by making available, clandestine shelters, false identity cards, medical supplies and clothing as well as, logistics and some arms. ${ }^{39}$ It is important, to note however, that despite the FLN-communist co-operation, which occurred at two levels, in countryside and in urban cities enforcing ZAA ranks with Communist Liberation Combatants, $\mathrm{CDL}^{40}$, in Algiers, connection remained very provisional, especially during the last phase of the war. In fact, part of those Communists of European origins soon changed camps and rallied behind the Pieds Noirs while propagating for "L'Algérie Française." Since then, it became public that FLN / ALN and communist cooperation was not genuine, due to cultural, ethnic as well as, ideological divide and this despite the existence of some Algerian individuals inside the communist front.

“...The chairman of the PCA Central Committee was Saddok Hajeres, a Jew appointed by Moscow's persuasion, as probably being more acceptable in any dispute between Muslims and Christians. Apart from minor co-operation on manufacturing and obtaining explosives, the two underground organisations in Algiers, the PCA and the ALN, had little to do with each other... the PCA formed a small paramilitary organisation in the city. The PCA probably had about 12,000 members of whom $80 \%$ were Europeans, many of Spanish descent, who sympathised with the Spanish Republicans. As the war progressed, there was a change of heart on the part of the EuropeanCommunists who turned against the Muslims, dropping their political activities and affiliations. Soon, most were loudly shouting for a "French Algeria". ${ }^{41}$ Finally, it can be said that the FLN-Communist connection was provisionally, desired by some FLN men, like Abbane Ramdane and his supporters and this was only for pragmatic reasons, but when it came to the principles of the Frontists, this link had always been rejected. The fact was that the national cause was more favoured by the ALN men than the international cause already propagated by international Communism.

The other challenge, which the FLN confronted, was from within the mainstream of Algerian nationalism represented by their fierce rival, the MNA or Messalists. Those, as the war developed, would seriously affect the FLN campaign, and cause its weakness in both Algeria and abroad, notably, in Metropolitan France.

\section{The ZAA Malaise and Causes of its Demise}

As urban guerrilla and counter-guerrilla coming from the French side developed, the ZAA knew a number of setbacks, which soon affected its strength and cohesion. Through intelligence, the systematic use of torture and abuse of the guillotine, the French Paratroopers, (who were given special powers) finally, succeeded in shaking the ZAA underground network, and forcing its 
survivors to disperse, and escape to - under FLN new directives - to the countryside to enforce the remaining rural maquis.

Most historians, particularly those who wrote about Algeria, often referred to the urban guerrilla by indicating the collapse of the Battle of Algiers in 1957 while ignoring its real facts and short-term objectives. They also, explained its failure by the 'heroic" actions of General Massu's Paratroopers in the Kasbah, but without considering other issues, like FLN's changing strategy and alteration in the style of fighting then resorting back to the countryside. We believe there are three important factors, which might perhaps explain the ZAA weakness and the urban network in Algiers, and these were:

1. The looseness of secrecy and gradual destruction from within the organisation itself as a result of French massive military and police retaliation through the use of systematic torture, guillotine and collective punishment of normal suspected civilians.

2. Leadership vacuum that was felt in the urban city, especially after the capture or elimination of some key leaders, or members.

3. The FLN's strategic decision to change its fighting-style and tactic, by resorting to the rural countryside, and focus besides, the rural struggle, on diplomacy abroad to propagate the Algerian cause.

1. With the accidental capture of some ZAA members, like Hassan Ghandriche who, under physical torture and interrogation accepted co-operation with France, the organisation started losing its strength, and became vulnerable to French infiltration. This began, especially when Ghandriche (a ZAA chief of region No. 3 under Yacef Saadi) was arrested on August 6th 1957, confessed then was forced to act as a double agent working for French intelligence. As a result, this facilitated French investigation and infiltration within the FLN's ZAA, but more important, it led to many other arrests of urban guerrilla operatives alongside other agents of liaisons. And under intensive torture, most of those were also forced to inform about their colleagues and their hideouts. ${ }^{42}$ Counter-terror measures in contrast, the French combined both Police and Paratrooper forces which finally, succeeded in detecting the first military zone, established at the Impasse of St. Vincent de Paul inside the Kasbah. By August 1957, the whole area was surrounded by the military and police, but without causing any major disaster to the whole ZAA movement. In retaliation and under FLN directive, the ZAA amplified the campaign with intensive bombing attacks aiming at a civil war that would provoke the French Ultra Pieds-Noirs to fight back and Algerian Muslim population that was ready and prepared for action and fight. But the colonial authorities, which looked at the problem as a danger and state security quickly, realised the threat and responded with the appeal to the French army to intervene. The French colonial administration also, thought that if the FLN was left free it would, certainly, provoke a full blown civil war in which the two communities would be massacred at the expense of what the colonial administration thought of "French Algeria". So in response, France retaliated with massive military force and called for harsh policy against the FLN and many of its civilian supporters. The fear of institutionalised course of torture, already adopted as a counter-terror tool by the paratroopers and its abuse surely brought not only Kasbah civilian population to its knees, but also FLN men and women who were caught.

2. With Paratroopers' challenging through coercion and intimidation, the ZAA began to finally show gradual and retreat from action, especially when it saw that Muslim civilians were being tortured and its prominent leaders either arrested and guillotined, or simply, dispersed or escaped to the maquis and closer to the eastern and western borders near Tunisia and Morocco. For instance, it was neither Bitat, nor Ouamrane or the rest like Krim Belkacem, Abbane Ramdane, Yacef Saadi or Youcef Ben Khedda who remained in the city. They all left leaving behind a real leadership vacuum. Further that the remaining, dispersed guerrilla cells were only led by sectorial chiefs who were 
confused as to whether carry on the fighting within their own areas, or to simply, respond to FLN's instructions and regain the countryside.

3. The FLN decision in changing its fighting strategy and style could be explained by two reasons:

1) As many difficulties and dangers mounted in the city FLN/ALN guerrillas began to evacuate and disperse living urban areas in Algiers, which became very vulnerable, especially after the capture of some of its key leaders. Also, this was decided to prevent total massacre of the Kasbah and surroundings' civilian Muslim population. By approving that decision the FLN had in a way left no excuse for the French paratroopers to continue their ratissage operations on civilians and massacre Kasbah dwellers. So, leaving the city on these grounds was the wisest strategy to follow.

2) The FLN leaders believed that the objectives behind the Battle of the city, like gaining publicity for the Algerian cause, popular support of the Muslim, and deterrence of the French PiedsNoirs) were all achieved and there was therefore, no need to remain in the city, especially when heavy French Paratroopers force was called for to intervene.

It is also, acceptable to believe that until now, there exist a number of misunderstandings, especially in some western writings when assessing the Algerian urban guerrilla and the FLN during the Battle of Algiers in 1957. There were still at that time views, which assumed that the FLN had failed in the city, because it could not launch the final armed revolution against colonial France, nor could it succeed in pushing the French Pieds-Noirs out from Algeria by force. Further, was that the rural guerrilla was also blamed for its inability to fulfil its full mission through an urban guerrilla strategy in order to launch the final armed revolution. The fact is that these arguments were / are undoubtedly, less applicable to Algerian reality and generally, do not, therefore, fit the communist and new-left patterns of Guerrilla strategy already experienced by the Vietnamese, Chinese, or Cuban. Neither the FLN, nor its military leaders in the ALN adopted that strategy; and that they would launch an urban guerrilla from the countryside to launch an armed final revolution. Also, that France was very strong and militarily well deployed and powerful, especially when Paratroopers were called in the city. It is worth adding, furthermore, that in communist thought and the new left theories, like the Guevarist model, the idea assumed that once the rural guerrilla develop and consolidate and strengthen it would launch an assault on the urban city with the aim to encircle it, invade it, clean it from informers and prepare for the final armed revolution. And within this framework the rural countryside, enforced by the peasants would finally win the campaign over the urban city, as project theoretically by guerrilla theoreticians, like Régis Debray, (and the strategy of the focco) Che Guevara (the minuet and firing groups) and the like. For them the graveyard of the revolution due to the strong implementation of enemy conventional forces, corruption and informers are strong but the city as a target in the final analysis is an objective. In the FLN in contrast, the city was temporary tactic to propagate the Algerian armed struggle and the Battle of Algiers was fought at a price once it had achieved some objectives.

General Massu in "La Vraie Bataille D'Alger", portrayed military weakness as a total failure, but gave also the reader an impression that the FLN had completely lost the war and the campaign. Massu, as a military man, perceived his victory in the city in purely, military terms and in only urban areas taking the Battle of Algiers as a key example, without trying to differentiate, for example, between the concept of guerrilla campaign (which is broader in meaning and forms) and the terror network led by an urban guerrilla in the city. His exposure of the Battle of Algiers as a nucleus is not very different from other views suggested by other writers, like Alistaire Horne, John Talbott or Martha Crenshaw. Those had mostly analysed the FLN as a terrorist organisation, or at least as a nationalist movement that extensively used terrorism, and its weakness in the city as a strategic failure. The fact was that the FLN did not - as cite earlier - preach the urban city as a nucleus as did for instance, Carlos Marighela in Brazil, to launch a final revolution, but its use was tactical and 
complementary to the rural countryside. The French Paras of the 10th division of General Massu applied a dual policy which one might call "hard and soft". While the former, consisted of selective and random arrests of civilians with objective to coercively extract useful information through interrogation the latter, aimed at the "de-popularisation" of the FLN through psychological actions and institutions, which the French army had already established. In action, however, the Paratroopers were found very unfit to carry out police duties investigation and dialogue, because of their lack or inexistent police training in urban environment. In contrast, they are designed for military confrontations, and conventional warfare rather than police work. So, it is not therefore, surprising to see them being challenged in the city of Algiers and its sub-suburbs, especially when dealing with civilian prisoners. This was perhaps, also due to the perceptions and decisions of their superiors. When they entered the city, they came with the view of the Algerian countryside and probably, the rural areas of Vietnam as most of those served in south East Asia. Jean Lartéguy stated that "The parachutes were organised to police method in practice but in their minds they were having the picture of the countryside". ${ }^{43}$

In order to implement their policy, the French authorities had further, deployed heavy military forces with a view to destroy FLN networks and build new ones. ${ }^{44}$ And in order to strengthen their case, the 10th division of paratroopers were granted by the authorities, power supremacy over all police and gendarmes forces into the city. ${ }^{45}$ As a result, Algiers became a military ruled town under the command of General Massu. And on January 7th, 1957, the army controlled all forms of life: The transport means and supplies, distribution of goods, the detention of products and raw materials and animals. Its special power also included the granting of sojourn passes to specific zones, arresting suspicious individuals, restricting meetings in places of attractions and drinks, confiscating arms and explosive to the civilians and furthermore instructing house-arrests. ${ }^{46}$ Operationally, Algiers also, became militarily divided into sectors: For example, the Senegalese and the troops of "Zouaves" already stationed at the headquarters of Orleans were put under the Kasbah, the Génie troops were stationed at Hussein-Dey, the artillery and anti-air forces at Fort L'Empreur, the transmission units at Ben Aknoun region and Maison Carreé, whereas the rail units were ordered to control Beni Messous region. ${ }^{47}$ The idea was to encircle the affected areas then to proceed with clean-up operations starting from the Casbah itself, and to further suffocate the remaining stuck guerrillas by preventing them from any contacts from outside. Yacef noted that "...During the period of the reorganisation 25 to 30,000 French soldiers permanently maintained the capital... On January 1957, the Paras and the Zouaves settled their guard-boxes all over the terraces of the Casbah transforming it into a concentration camp. Twenty four hours every day, the patrols and regiments of "Ratissage" systematically searched house by house, angle by angle...I changed my shelter seventeen times escaping miraculously... the sisters Hassiba, Zohra and Djamila [ZAA's Fidayait: female guerrilla fighters] with the brothers Ali la Pointe, Cherif Debih aka, Si Mourad and Omar my young nephew all followed me successively in my escape and sharing the same dangers". ${ }^{48}$ The streets which related to the Casbah from the rest of the town were also locked up and encircled with wires. Patrol detectors were installed in all Muslim quarters day and night. But despite these strangling methods, the ZAA managed with great precaution and little results to carry out some urban operations in order to bring back the morale to its men and show signs of its existence to its Muslim supporters. But in contrast, the French paratroopers who were very superior in men and armament, were challenging with massive arrests and alarming torture. For example, out of the total population of the Kasbah of 80,000 , there were according to Edward Behr, $30 \%$ to $40 \%$ of its active, male population arrested for questioning and tortured. ${ }^{49}$ Although torture had led to the extraction of useful information and destruction of some FLN cells in the city, it brought, on the other hand, sympathy to the Algerian cause even from French intellectual circles. ${ }^{50}$ It remarked that "The battle of Algiers brought the use of torture hitherto a shadowy affair, widespread public attention... in early 1955, the leftist journalist Claude Bourdet, a member of the resistance and survivor of a German concentration camp, published a piece called "Your Gestapo in Algeria... the Paras claimed that the struggle against urban terrorism 
left them no choice; such methods spared innocent lives. What would you do, they asked, if you had in your hands a terrorist whom you knew had hidden a bomb in the city set to explode within the hour? ... But in fact, few of those whom the Paras interrogated were "terrorists". Most were collectors of funds, messengers, relatives of known members of the FLN', ${ }^{51}$

\section{Conclusion}

Summing up, it can be noted that it was only through a large campaign of torture, which the French forces initiated that France succeeded to provisionally, bring calm to the city while partially, destroying some FLN cells ${ }^{52}$ But without totally suffocating the general FLN campaign. Unlike the guerrilla "Focco" of Régis Dray, or the "Firing Groups" of Carlos Marighela, the Algerian course favoured the concept of world-wide campaign in general. A combination of rural and urban city guerrillas were well coordinated and proved very complementary during the struggle. Operationally, the rural and urban guerrillas, despite their difference, were sometimes inter-changeable in action, and both of them fought their ways while selecting their own tactics while considering options and risks of the general situation. The intensification of the urban campaign despite its "Malaise", had assisted the rural countryside to grow and consolidate in a number of domains. For example, in sending food and medical supplies smuggled from hospitals as well as, other logistics, in transmitting FLN propaganda and in providing recruits of volunteers to the maquis. Militarily too, its assistance was in dragging French forces to the city giving them the impression that the heart of the guerrillas was there while allowing the countryside to develop and amount armed attacks on French European colons and military installations. ${ }^{53}$ Through this model, the Algerian FLN managed to maintain survival internally as well as externally at the borders. "It was fascinating to watch from a central position the disintegration of the FLN armed forces, albeit at immense cost to France in terms of financial expenditure and military effort. But it became clearer with each passing day that, with sanctuaries to their east and west, the FLN could never be entirely eliminated while the spirit of their leaders remained alive". ${ }^{4}$ The maintenance of the campaign lay militarily on the FLN's success of mobility with its full knowledge of the terrain, and in forcing the French forces to follow without strategic results, especially at the borders where the ALN men were conventionally prospering. ${ }^{55}$

Military victory is not in our view, chasing a guerrilla band from the city nor in the partial destruction of an underground cell with explosives and bullets, but it is in fact when the army and military forces succeed with bullets and pamphlets (psychological warfare and actions), with deeds and creeds by winning the hearts and minds of the population (Which is the most vital factor to any guerrilla, or counter-guerrilla force). So, it is irrelevant therefore, to undermine the political will or systematically isolate it from military matters in guerrilla warfare. The French army forces had won large parts of the terrain, because of their military strength, but definitely not the souls and minds of the Muslim population.

FLN urban guerrillas were temporarily, exploited as a tactical force using both intimidation and terrorism against French military and European civilian settlers as targets. Once they achieved their first goals using Muslim popular support, gaining publicity and instilling a state of fear in the city, they finally, retreated to the rural countryside. The Battle of Algiers might have militarily been lost, but the French did not win it politically. This as the war developed, the French lost the campaign and souls and minds of the people whereas the FLN won it, including diplomatically. With worldwide recognition and despair of the French Pieds-Noirs, France was finally forced to negotiate then confirmed its disengagement letting down supporters of French Algeria altogether. 


\section{Notes}

${ }^{1}$ Algiers was given at the Summam Conference of 1956, a special status because of its location and nature. It was divided into three main targets: Algiers Centre, Algiers West and Algiers East, where each part was directed by a "Council" divided into three branches: 1 - Politico-military; 2 - Financial; and 3 - Intelligence. For further information refer to Philippe Tripier in "L'Autopsie de la guerre d'Algérie", p. 197.

${ }^{2}$ Tripier, Philippe. L'Autopsie de La guerre d'Algérie, Paris Editions, France-Empire, 1972, p. 131.

${ }^{3}$ Ibid, p. 134. At the Summit, the politico-financial branch was directed by the Zonal Political Commissar who was also at the same time the politico-financial chief's assistant to the ZAA. Philippe Tripier estimated the Autonomous Zone of Algiers finance at the end of 1956, from 100 to 20 million of old French Francs per month. "Autopsie de la guerre d'Algérie". Paris, éditions, France-empire, 1972, p. 134.

${ }^{4}$ Fidayeen or a Fidai is an urban guerrilla fighter ready to carry out delicate missions and die for the cause.

${ }^{5}$ Ibid, p. 132.

${ }^{6}$ Yacef, Saadi. Souvenir sur la Bataille d'Alger, Paris, 1962, p. 35.

${ }^{7}$ Tripier, Philippe. L'Autopsie de La guerre d'Algérie, p. 133. The head of the zonal branch directed by five committees forming some kind of an "Etat-Major' and was partially put at the service of the CCE: The Committee of Liaisons ensures the clandestine mail with the military Wilayas, the FLN's federation in the Metropole, the organisation of the FLN with the CCE and with the forces already established in both Tunisia and Morocco. The Committees of intelligence were in charge of spying on the French administration and on the Muslim Unities working for France. The Committee of the Press was in charge of informing the consul of zones, propaganda circulation as well as for psychological actions. The Committee of justice was in charge of control over the execution of directives already decided by the central organ. The Sanitary Committee was dedicated to medical supplies and medicine preparation and was assigned to work towards the creation of an Algerian Red Cross. And finally the trade unions-committee was in charge of organising and leading workers' strikes and protest marches. Despite this detailed specialisation, there were common duties where one branch would occasionally do the other's work in order to maintain survival in case of French detection.

${ }^{8}$ Yacef, Saadi. Souvenirs sur la Bataille d'Alger, p. 10. Reserve-Networks were led by a prominent militant called Zoubir Bouadjadj, who was responsible for La Redoute-Clos-Salembier, Bir Mandraeis, Ruisseau and Belcourt sectors. On November 16th 1954 Zoubir was arrested with his group consisting of: Belouizdad, Merzougui, Kaci Abdallah Mokhtar, Kaci Abdallah Abderrahmane and Guesmia, as well as Yacef himself. ibid.

${ }^{9}$ Tripier, Philippe. L'Autopsie de La guerre d'Algérie, p. 233. See also Yacef, Saadi. Souvenirs sur la Bataille d'Alger, p. 20.

${ }^{10}$ Yacef, Saadi. Souvenirs sur la Bataille D'Alger, Tome I, Edition Unité de Reghaia 1984, p. 86.

${ }^{11}$ Ibid, p. 137.

${ }^{12}$ Pêgre: is a French word meaning the pimp's milieu and brigandage. It consisted of men and women who were entangled in prostitution, gambling, black markets and drug smuggling.

${ }^{13}$ Ali la Pointe: was the first individual pimp who converted to the FLN's urban guerrilla. His real name was Ali Ammar originating from Miliana. He was Yacef's henchman and later became his lieutenant throughout the war until his death.

${ }^{14}$ Ibid, pp. 151-152. In a secret meeting between Ali La Pointe, Yacef Saadi, Ahmed Chaib, Cherif Debih and Salah, Algiers was divided into three regions: The first consisted of Chateau Neuf, El Biar, La Casbah, La Ville Europeenne and Champs de Manoeuvre East. Second, of Maison Careé passing by Belcourt-region, ClosSalembier, La Redoute, Kouba, Birmandreis, Hydra and Hussein-Dey. As regarded the third part, it covered Bab El Oued to Guyotville, Beau Fraisier, Frais Vallon, Notre Dame d'Afrique and Saint Eugene to the west.

${ }^{15}$ Ibid, pp. 157-58. This was the case of "Bud Abbot" who was shot by Ali La Pointe for his collaboration with France. The lists of those executed by the ZAA's members were many. For instance, the "Sous-brigadier" 
Sahraoui a pro-French, by Ali La Pointe and Hamadi on April 19th at 20.55pm at 28 of La Rue Brahim Fatah. Merakeche Mohamed was also executed by Ali La Pointe whereas; Medjebri another pimp enemy was liquidated by FLN agents in Paris. Hocine Bourtachi "Le Bonois" was suppressed by Omar Hamadi, an FLN man at 3 Rue des Abderames.

${ }^{16}$ Yacef Saadi in "La Bataille D'Alger" estimated the MNA strength in the city (during that period) to 3,000 members, p. 161.

${ }^{17}$ Ibid, p. 161.

${ }^{18}$ For example, that "Europeans and Muslims were not socially and residentially segregated: They lived in the same quarters, mixed, ate and drank together". World Today, Vol., 18, No. 4, April 1962, p. 136.

${ }^{19}$ The term of French Europeans or Europeans is used her to refer to the French by nationality or by birth, or origin including the Jews of Algeria who had been granted French citizenship and rights in accordance with the Cremieux Decree of 1871.

${ }^{20}$ For example, the low Casbah was absorbing an enormous number of shanty towns: Cité Mahieddine, El Kettar, Fontaine Fraiche, Les Flancs du ravin de la femme sauvage, clos Salembier and clos d' H.Dey. Pierre Chaulet, "Parti Pris". Majallat Ettarikh (Journal of History), No. 17, 2e Semestre, Alger, 1984, pp. 82-83.

${ }^{21}$ Chaulet, Pierre. Parti Pris, p. 83.

${ }^{22}$ Behr, Edward. The Algerian Problem, pp. 111-12.

${ }^{23}$ Lartegy, Jean. Les Centurions, Press de la cité Paris, 1960, p. 327. See also Mansell, Gerard. Tragedy in Algeria, Oxford University Press, London, 1961, p. 59.

${ }^{24}$ Horne, Alistair. A savage war of Peace, pp. 191-192.

${ }^{25}$ Megherbi, Abdelghani. Culture et Personnalité Algerienne de Massinissa à nos jours, Enterprise nationale du livre, Alger 1986, pp. 33-37.

${ }^{26}$ Fares, Mohamed. La Participation des travailleurs Algériens émigrés en France á la lutte de Libération Nationale 1954-1962, Colloque International d'Alger, 24 Novembre, Alger, Bruxelles, 1984, pp. 109-125.

${ }^{27}$ Yacef, Saadi. La Bataille d'Alger, p. 144. A Fidai or a Fidaiya is a soldier of the national liberation army specialised in urban guerrilla warfare. He or she can be a simple soldier or a responsible officer of intelligence of many armed groups, or of an entire military sector. The Fidai should not know - in the ZAA and the FLN's lexicon - more than three members of the structure, whom he usually operates with: (The leader who chooses him and two other advisers only). The contacts between the three must be however, through writing or contacts at meeting points usually in public places viz.: cafés, public Turkish baths, shops and open markets. The managers and keepers of these properties know only the superficial aspects of the general meetings. The messengers do not reveal their messages unless the secret password is given. Most of the time members of the organisation operate at the same place, and at the same time, but without knowing each other.

${ }^{28}$ Ibid, pp. 232-235. Ahmed Zabana was captured on May in a bloody confrontation against the French army near St. Denis Sig $50 \mathrm{~km}$ of Oran, as for Abdel Kader Ferradj, he was arrested later. In order to increase the morale of the Muslim population, the FLN declared in a written tract that "all executions of the captured Combattants would be avenged, one Algerian Muslim for ten French civilians". Yacef himself had instructed one of the firing groups of La Rue des Thébes ordering them to stick on the victim's body: Zabana, Ferredi you are avenged, ibid. p. 235. There was also the bombing of La rue des Thébes claimed by the Ultra pied-noirs.

${ }^{29}$ Alistaire, Horne. A Savage war of Peace, p. 183.

${ }^{30}$ Apart from the very few Jews who were members of the Algerian Communist Party and sympathisers with the ALN cause such as Sadok Hajres, the others were entirely perceived by the FLN, as pieds-noirs and supporters of the colonial administration.

${ }^{31}$ Campbell, Arthur. Guerrillas: A History and Analysis, Liverpool, London and Prescot 1967, p. 239.

${ }^{32}$ Horne, Alistair. A savage war of peace, p. 184. 
${ }^{33}$ Ibid, p. 286.

${ }^{34}$ Ibid, p. 191. O'Ballance wrote that "This [Method] caused fear and uneasiness, which in turn resulted in tying down more troops on security duties in the cities, and so leaving fewer available to hunt insurgents in the mountains and countryside", O'Ballance, Edgar, The Algerian insurrection, p. 54.

| $58 \quad{ }^{35}$ Yacef Saadi, La Bataille d'Alger, pp. 41-42. A - Yacef gave Taleb Abderrahmane three weeks to do an experiment. After the consultation of useful book on Pyrotechny which was elaborated by a French colonel during the First World War but was irrelevant compared with the new techniques and on Dimitrium Aphtalen [a theory generated by a German scientist L. D. called Von Brawn at the University of Berlin, Taleb adopted the name of Schneidrite (Naphtaline, Nitric acid and sulphuric) to establish the first bomb for the FLN. Taleb Abderrahmane who was a brilliant student of chemistry at the faculty of Algiers became an FLN militant in March 1955 and was introduced to the ZAA by H'Didouche, and Salah Bazi in the Casbah in a place called "L'impasse de la grenade]. Yacef, Saad. "La Bataille d'Alger". Tome I, pp. 227-243. B - The bombing campaign required big personnel where everyone was in charge of a specific duty. Names viz: Marsali Abdelghani, Mustapha Bouchouchi, Rachid Kouache, Abdelkader Ladjali, Ali Berrezouane, Cherif Debih etc. were amongst the first volunteers to prepare the bombs by providing clocks, wooden boxes and detonators to practice on. Yacef argued that they were working up to ten hours per day except during the time of curfews where they had to hide their pieces of equipment. "During the bomb's mounting we needed all the experts at the same time". The first bomb was born on August 22nd 1956 and was tested at a small beach called "Plage des Chevaux" located in Bab El Oued where the volunteers of death were chosen according to their degrees of courage and their command of the French language. Ibid, p. 282

${ }^{36}$ Ibid, p. 29.

${ }^{37}$ Ibid, p. 248.

${ }^{38}$ Teguia, Mohamed. L'Algérie en guerre, pp. 272-73.

${ }^{39}$ Ibid, p. 288. It was agreed that the communists would be operating under the control of the FLN only and would have no links with their former party all throughout the war. As regarded the party itself, it was allowed to maintain its political autonomy. Its leaders who had not been arrested viz: Bachir Hadj Ali and Sadok Hadjres remained in Clandestineity in the interior of the country until the day of independence. See also Yacef, Saadi. La Bataille d'Ager, p. 151. Teguia, Mohamed. L'Algerie en guerre, p. 287. The communists had good implementation within the Aures and the Cheliff regions and amongst the peasants of Themcen region. There were also other communist - "Foyers" around Ain M'Lila within the Constantinois, Sidi Bel Abbes and amongst the nomads of Ain Sefra regions. Ibid, p. 276. The case of Henri Maillot, a communist who deserted the French army on April 4th 1956 with a lorry of arms and ammunition was helpful to the FLN, because part of it had been directed to the maquis. Mohamed, Tenguia estimated this armament at 126 machine guns, 62 shot-guns, 84 revolvers, and a thousand rounds of ammunition, a quantity to arm two Katibas and several groups. For further information refer to Teguia, M. L'Algérie en guerre, p. 279. The examples were many: For instance the combined assassination of Gerard Etienne (a prominent ultra and anti-FLN, a cinema and a bar' owner) who was famous for his plots against Muslim civilians in bombing and kidnapping. The operation was allocated to Yahia Briki assisted by Abdel Kader Ben Barek. Yacef, Saadi, La Bataille, p. 271. There was also, the case of Fernand Yveton who was supposed to bomb the Gaz factory of "La Compagnie Lebon" and failed, then was captured by the French police and guillotined. Ibid, pp. 65-66. On the collaboration of the communists with ZAA - FLN members, see also, Djamila Bouhired' testimony, Majalat Ettarikh [History Magazine], Centre national des Études historiques, pp. 109-111.

${ }^{40} \mathrm{CDL}$ : Les combatants deliberation d'Alger was allocated to a communist called Mr. Benzine from September to December 1955 and assisted by Mr. Georges Acampora, in military questions and Andre Castel, in liaisons and supplies. See Teguia Mohamed, L'Algérie en Guerre, pp. 272-273.

${ }^{41}$ O'Ballance, Edgar. The Algerian insurrection, p. 151.

${ }^{42}$ Ghandriche who was put in a flat at "La Rue d'Isly near cinema "Marivaux" started operating as a double agent and informing about his FLN colleagues through messages. Through these writings and contacts Ghandriche, managed to discover Yacef's hideout, and on September 24th 1957 around ten thousand Para, Zouaves and gendarmes surrounded, at mid-night, the Casbah. The intention was to blow up the whole area 
with TNT, but after Yacef accepted surrender in order to save the inhabitants and the remaining hidden groups, the Paras had changed their minds.[Today, a large part of the inhabitants of the Casbah still believe that it was Yacef himself who sold Ali la Pointe and his group]. See Yacef, Saadi. Souvenirs sur la Bataille d'Alger, p. 116.

${ }^{43}$ Lartéguy, Jean. Les Centurions, Press de la Cité, Paris 1960, p. 380.

44 Talbott, John. The Myth and Reality of the Paratrooper in the Algerian War, Armed Forces and Society, Vol. 3, No, 1, November 1976, p. 71. He noted that "By the end of 1956, France had committed an armed force of more than 400, 000 men in an effort to make good this pledge", pp. 71-72.

${ }^{45}$ Massu, Jack. La Vraie bataille d'Alger, Paris, PLON 1972, p. 44.

46 Talbott, John. The Myth and Reality of the Paratrooper in the Algerian War, p. 73.

${ }^{47}$ Massu, Jack. La Vraie bataille d'Alger, pp. 30-32.

48 Yacef, Saadi. Souvenirs sur la Bataille d'Alger, p. 35.

${ }^{49}$ Behr, Edward. The Algerian Problem, p. 114.

50 Jules, Roy in "J' accuse le général" wrote that "Because of torture which we had already practised in Indochina I left the army... you know better that there were not only the bombs of the FLN which would kill the children... the kids who escaped our bombardment were already training themselves at manipulating arms... those who resisted you were neither barbarians nor "Bougnouls" [stupid], but they were men who could not stand the oppression". Edition du Seuil, 1972, pp. 31-32.

${ }^{51}$ Talbott, John. The Myth and Reality of the Paratrooper in the Algerian War, p. 76. See also Yacef, Saadi. Souvenirs sur la Bataille d'Alger, p. 40.

52 Behr, Edward. The Algerian Problem, pp. 114-5. See also Soustelle, Jack. The Algerian Tragedy and the Problems of Africa, World Today, August 1957, Vol. 13, No. 8, p. 325. Although the French Paras managed to destroy some FLN's cells, their psychological warfare against the FLN and the civilians had finally failed. For further information refer to the Press Conference of Colonel Bigeard in Le Monde, 28 Aout, 1957, p. 4. Colonel Masey, in Le Monde, 31 Aout, 1957, p. 5. Also in Sherman, Alfred. Climax in Algeria, World Today, Vol. 18, No. 4, April 1962, p. 139.

${ }^{53}$ Le Colonel Sadek. Notre Armeé et sa Stratégie, Commander of Wilaya IV, El Moudjahid, 20 Aout, 1957, Volume I.

${ }^{54}$ Campbell, Arthur. Guerrillas, p. 241.

55 Breastrup, Peter. Partisan war: Algerian Style, p. 393. He noted that "The rebels adapting tactics to resources, coupled mosquito war with skilful, if crude, political action. Their cause gained strong emotional staying power among the Muslim masses, a power to which the French have devised no effective answer. The rebels relied on the long pull, militarily and politically. The French long sought, and have repeatedly claimed, imminent military victory. The Algerian war... has progressed after more than five years to the point where, a purely military solution seems no longer possible. Both sides have arrived at a stalemate. Any breakthrough will have to be achieved at the negotiating tables". Ibid. 